\title{
Secondary encapsulating peritonitis: a study of cases over five years
}

\author{
Mansoor Banday ${ }^{1}$, Sehrish Rauof ${ }^{2}$ \\ 1 Department of General Surgery, Esi Postgraduate Institute of Medical Sciences and Research and Hospital, Basaidarapur, New Delhi, India \\ 2 Department of Nephrology, Government Medical College, Srinagar, India
}

\begin{abstract}
Objective: Cocoon abdomen or sclerosing encapsulating peritonitis is a rare condition characterized by bowel entrapment in a cocoon-like membrane. Primary and secondary types have been described. Most patients present acutely with intestinal obstruction or peritonitis but history of long standing chronic symptoms may be present. The condition is usually not detected on imaging, and diagnosis at laparotomy is common. Surgical treatment includes excision of the membrane with adhesiolysis.
\end{abstract}

Material and Methods: A 5-year study of the patients operated for cocoon abdomen in our hospital was conducted. Analysis of patient symptoms, imaging findings, intra-operative findings and histopathology was carried out.

Results: Five males and three females were included into the study. Mean age was 29.6 years. Five patients presented with acute intestinal obstruction and three patients with perforation peritonitis. Laparotomy was performed in all cases. Successful excision of the membrane was done in all patients of obstruction while membrane excision could only be done in one patient of peritonitis. Histopathology revealed tuberculosis in six patients, one patient was already on anti-tubercular treatment and one patient had carcinoma. There was one mortality.

Conclusion: Cocoon abdomen is a rare condition. Tuberculosis should always be considered as a cause in endemic areas. Surgery is the preferred treatment and involves excision of the membrane but can be difficult in patients with superadded peritonitis or malignancy.

Keywords: Cocoon abdomen, perforation peritonitis, sclerosing encapsulating peritonitis, tuberculosis, cocoon carcinomata

Cite this article as: Banday M, Rauof S. Secondary encapsulating peritonitis: a study of cases over five years. Turk $J$ Surg 2019; 35 (3): 171-177.

\section{Corresponding Author}

Mansoor Banday

E-mail: mansur.banday@gmail.com

Received: 08.03.2018

Accepted: 24.04 .2018

Available Online Date: 23.09 .2019

(C) Copyright 2019 by Turkish Surgical Society Available online at www.turkjsurg.com

DOI: $10.5578 /$ turkjsurg.4143

\section{INTRODUCTION}

The term cocoon abdomen was first used by Foo et al. in 1978 when they described plastic adhesions with a fibrotic membrane occurring in young adolescent females in a virgin abdomen (1). Peritonitis chronica fibrosa incapsulata and sclerosing encapsulating peritonitis (SEP) are the other terms used in the literature for the same condition (2). The condition is characterized by partial or complete encapsulation of the bowel resulting in bowel obstruction of varying degrees associated with an inflammatory process of the peritoneum. A separate distinct condition is primary peritoneal encapsulation which is essentially a congenital duplication of the peritoneum in the absence of any inflammatory or sclerotic process (3). A preoperative diagnosis is seldom made and most of the cases are detected at laparotomy performed for small bowel obstruction. Histopathological analysis of the membrane provides a definitive method of ascertaining the underlying etiology.

\section{MATERIAL and METHODS}

We analysed the patients with an intraoperative finding of cocoon abdomen operated in our hospital over the past five years from 2013 to 2017, and eight such cases were identified. The study included five patients who presented prospectively and three cases which were identified retrospectively. Only patients with a virgin abdomen were included into the study and patients with any history of abdominal surgery were excluded. Study of patient characteristics including symptoms, abdominal signs, imaging findings, intra-operative findings and histopathological analysis were implemented (Table 1). Informed consent was taken from all the patients before surgery. Ethics committee approval was not needed as all patients presented with acute abdomen and needed surgical intervention. 


\begin{tabular}{|c|c|c|c|c|c|c|c|c|c|c|}
\hline & 㟋 & 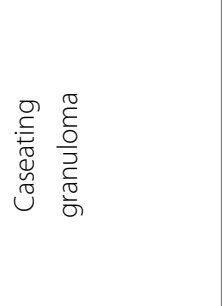 & 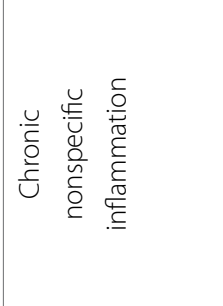 & 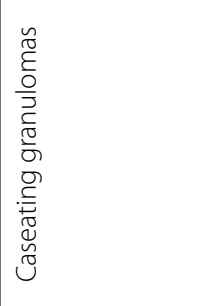 & 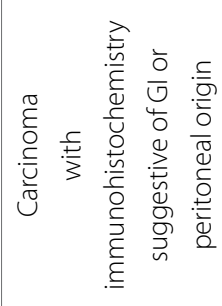 & 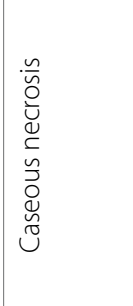 & 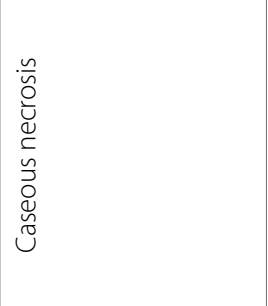 & 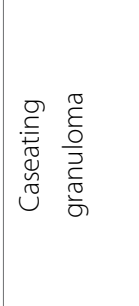 & 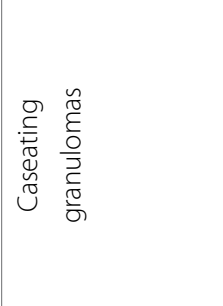 & \\
\hline & 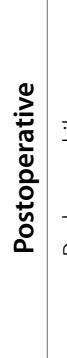 & 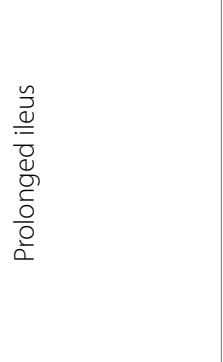 & 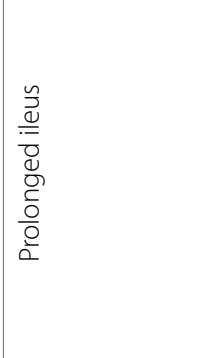 & 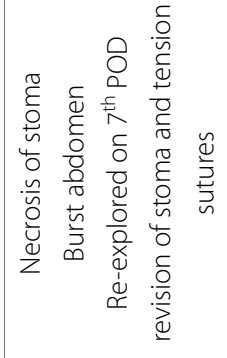 & 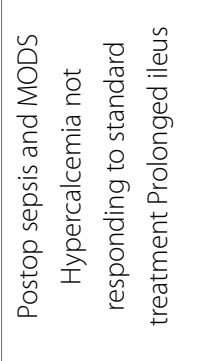 & 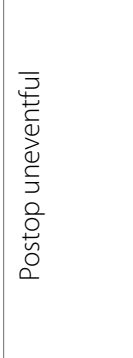 & 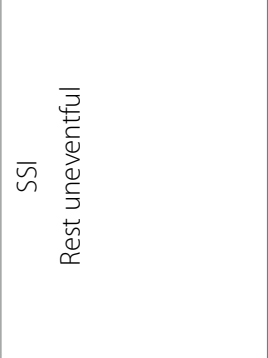 & 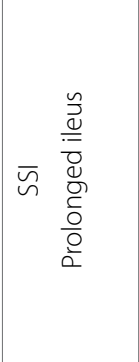 & 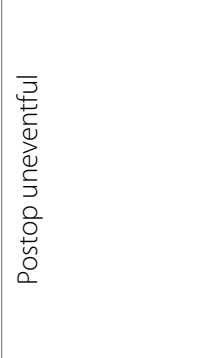 & \\
\hline & 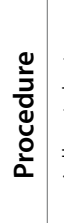 & 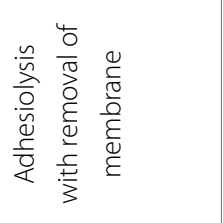 & 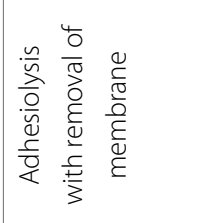 & 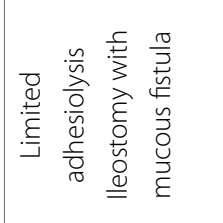 & 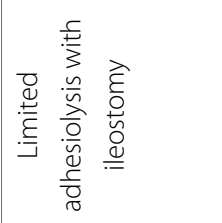 & 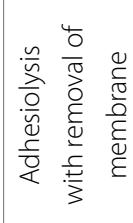 & 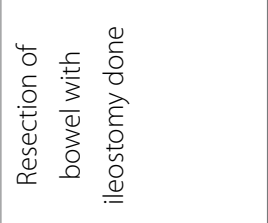 & 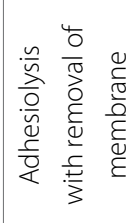 & 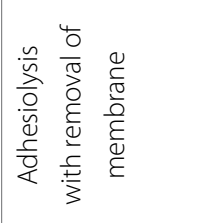 & 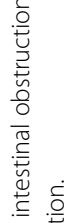 \\
\hline & 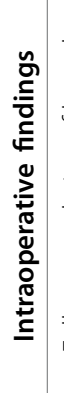 & 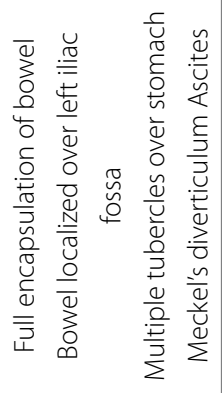 & 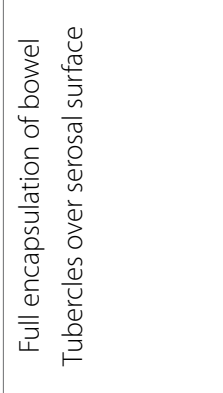 & 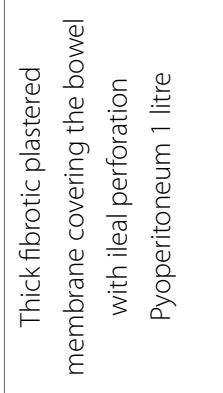 & 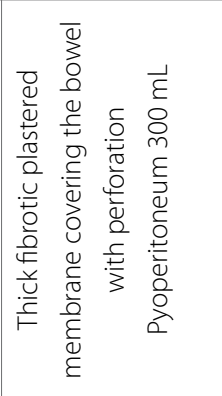 & 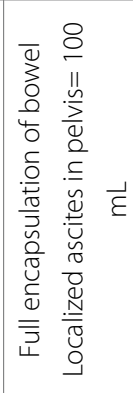 & 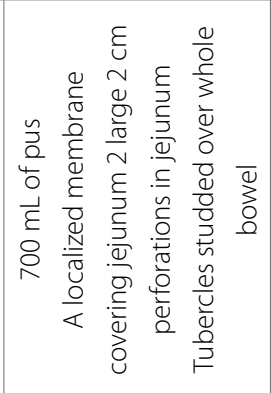 & 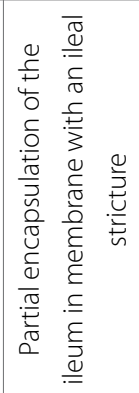 & 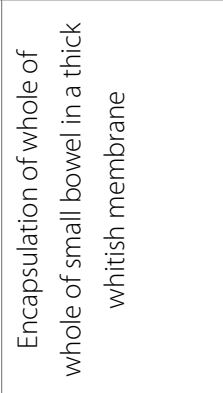 & 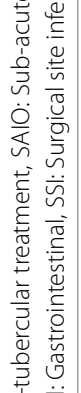 \\
\hline 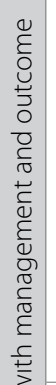 & 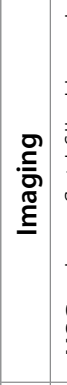 & 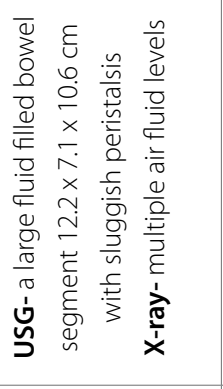 & 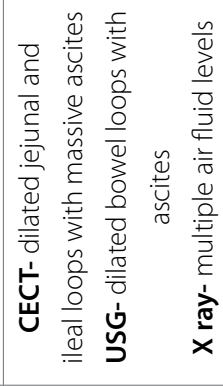 & 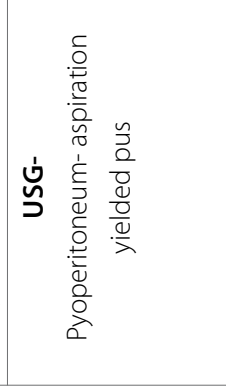 & 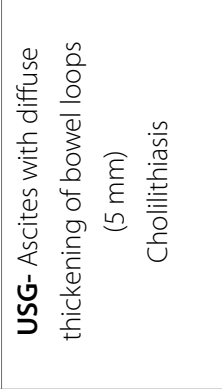 & 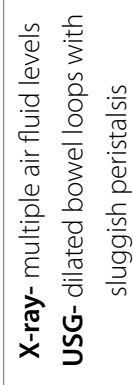 & 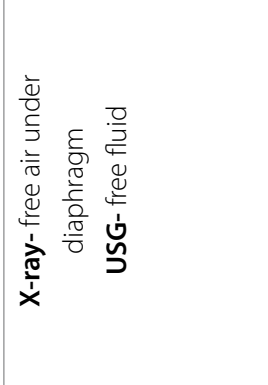 & 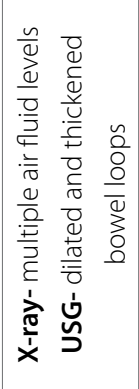 & 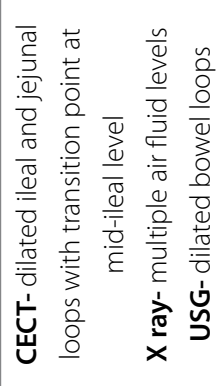 & 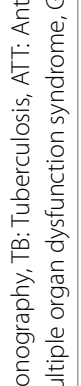 \\
\hline 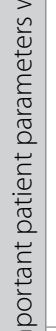 & 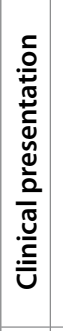 & 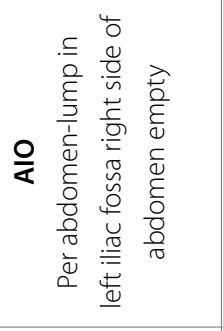 & 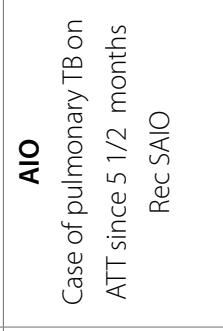 & 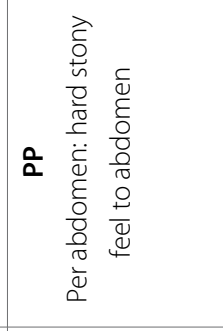 & 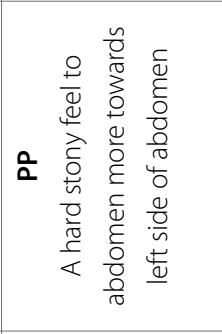 & 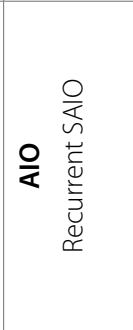 & $\stackrel{a}{a}$ & 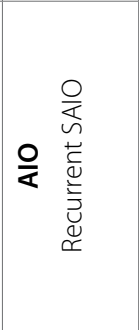 & 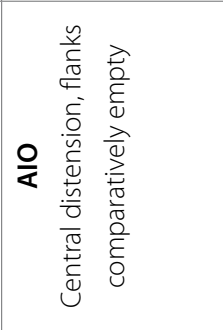 & 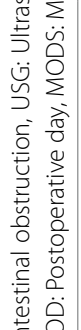 \\
\hline & $\begin{array}{l}\widehat{\widehat{v}} \\
\stackrel{\mathrm{U}}{\mathrm{g}} \\
\stackrel{\mathrm{Q}}{\mathrm{Q}}\end{array}$ & $\underset{\infty}{\infty}$ & $\underset{0}{2}$ & $\grave{\lambda}$ & $\underbrace{2}_{0}$ & $\underset{m}{\stackrel{2}{n}}$ & 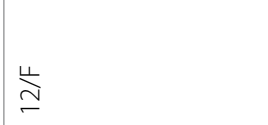 & ১্ল & $\stackrel{\stackrel{\sim}{m}}{m}$ & 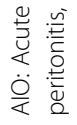 \\
\hline
\end{tabular}




\section{RESULTS}

Mean age of the patients was 29.6 years (ranging from 12 years to 60 years). There were five males and three females. Five patients presented to us with features of acute intestinal obstruction $(\mathrm{AIO})$ and three patients presented with features of perforation peritonitis (PP).

Patients presenting with $\mathrm{AlO}$ had features of small bowel obstruction like acute abdominal pain, vomiting, abdominal distension and obstipation. Three patients had history of recurrent episodes of subacute intestinal obstruction (SAIO), others presented more acutely with only 4-5 days history. Of the three patients with $\mathrm{AlO}$, two had disproportionate distension of the abdomen confined to one half of the abdomen. In one patient, the distension was mainly confined to the left side of the abdomen, initially giving a suspicion of sigmoid volvulus while the right side of the abdomen felt empty on palpation. The $2^{\text {nd }}$ patient had central abdominal distension with comparatively empty bilateral flank region. One of the patients was a known case of pulmonary tuberculosis taking anti tubercular treatment (ATT) for the last five and a half months.

In patients with perforation peritonitis, one had typical guarding and rigidity associated with PP. In the other two patients, a more stony hard feeling on palpation was present, which was different from the normally seen rigidity and guarding in PP patients.

Abdominal X-ray was done in all cases. All AIO patients showed multiple air fluid levels on radiograph. Only one patient with PP showed free gas under the diaphragm. Ultrasonography (USG) was done in all patients which showed features consistent with $\mathrm{AIO}$ and PP in the respective group of patients but no features suggestive of any cocoon were present. Computed tomography (CT) abdomen conducted in two cases showed thickening of the bowel loops in one patient with a suspicious membranous layer engulfing the bowel and dilated bowels loops with a transition point in the other patient.

Intraoperatively, in patients with $\mathrm{AlO}$, four of the 5 patients had a thick whitish membrane engulfing whole of the small bowel (Figure 1), and in one patient the membrane was only partially engulfing the bowel with a part of the bowel free. Adhesiolysis was done in all cases and the whole of the membrane was excised out.

In two patients of PP, in contrast, the membrane was not delineable and instead a plastered cemented layer (Figure 2) was covering the whole of the bowel. In one patient, iatrogenic injury occurred while dissecting and with much difficulty the site of injury was brought out as a double barrel stoma. Another peculiar thing in this patient was that the mesentery was virtually non-existent and only small sub-millimetric vessels arising from within the cocoon supplied the bowel with the mesenteric fat totally resorbed into the inflammatory process. Another pa-

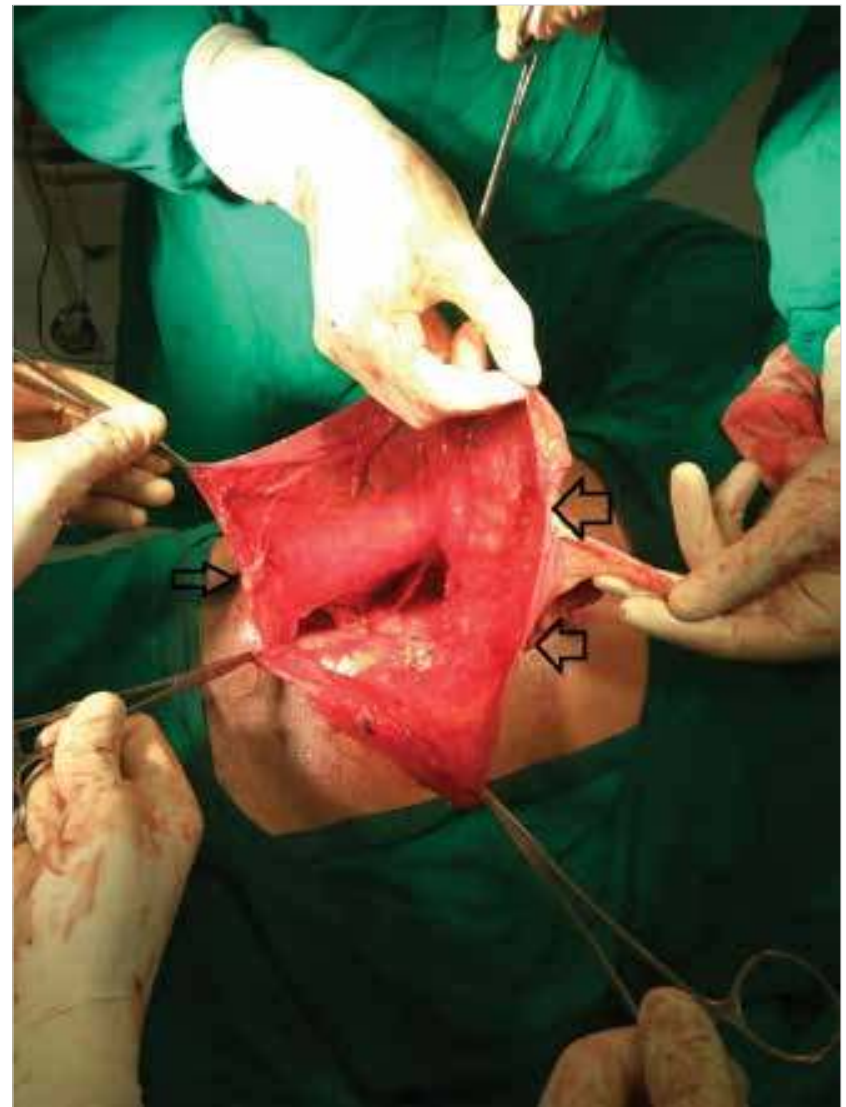

Figure 1. Encapsulating membrane opened (arrows) with underlying bowel.

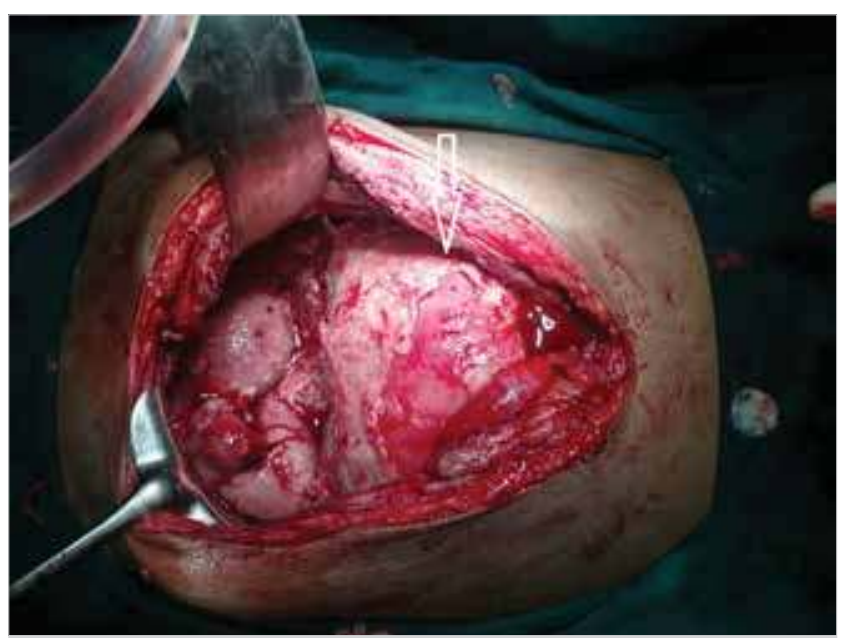

Figure 2. Plastered cocoon in a patient with peritonitis (arrow).

tient in this group presented with the same abdominal finding of plastered cocoon, an ileostomy was done in this patient and few bits of tissue from the adhesions were sent for biopsy which revealed carcinoma (Figures 3 and 4), immunohistochemistry $(\mathrm{IHC})$ of which was suggestive of possible origin from gastro-intestinal (Gl) tract or peritoneum. In the $3^{\text {rd }}$ patient, after sepa- 


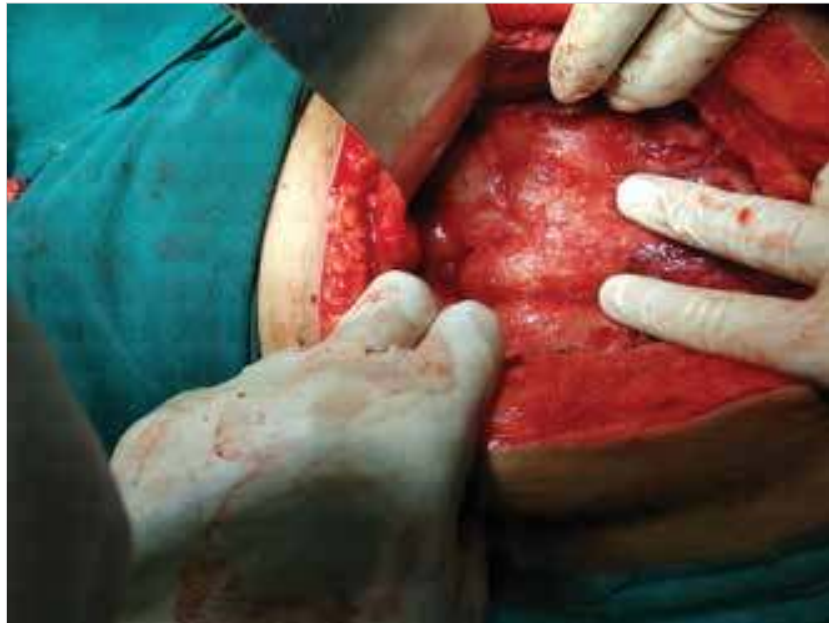

Figure 3. Cocoon with a fibrotic membrane of cancer.

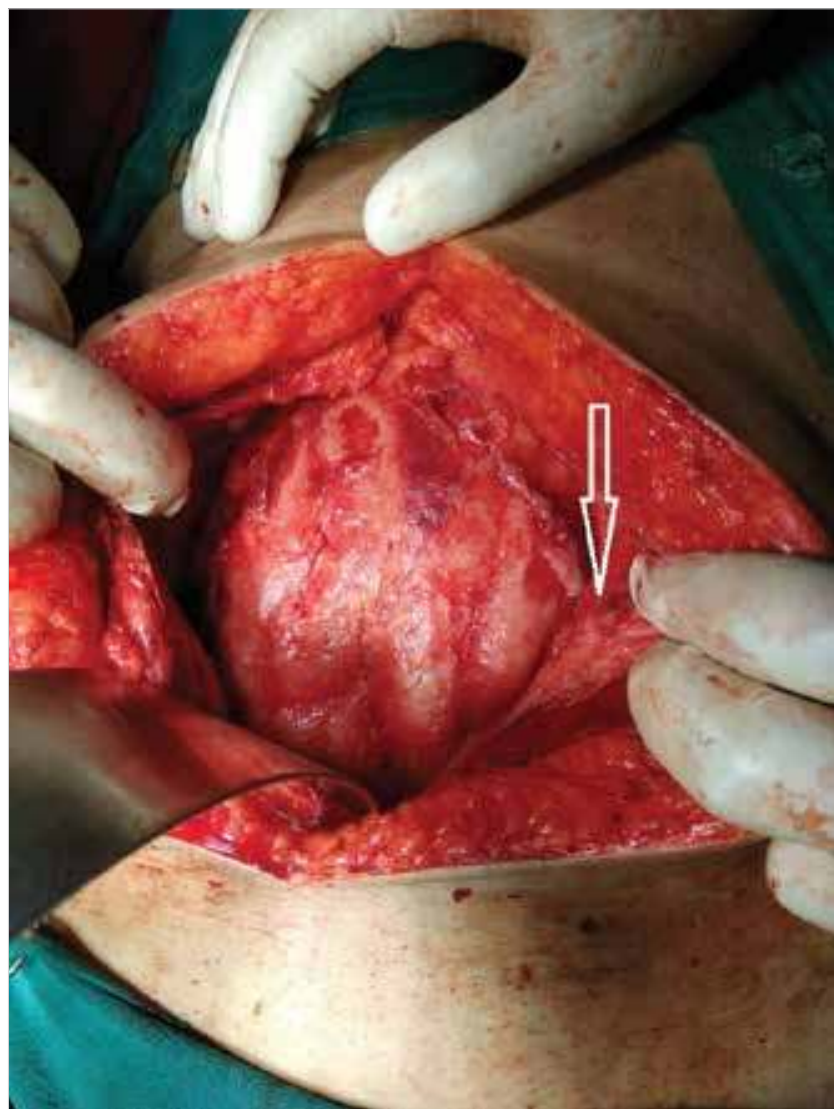

Figure 4. Matted bowel loops with overlying thick peritoneum (arrow).

rating the cocoon membrane, two perforations $(=3 \mathrm{~cm})$ were found in the jejunum and whole of the serosal surface of the bowel was studded with tubercles (Figure 5). Resection of the perforated segment with ileostomy was done.

In the post-operative period, among patients with $\mathrm{AlO}$, two patients developed surgical site infection (SSI) managed with

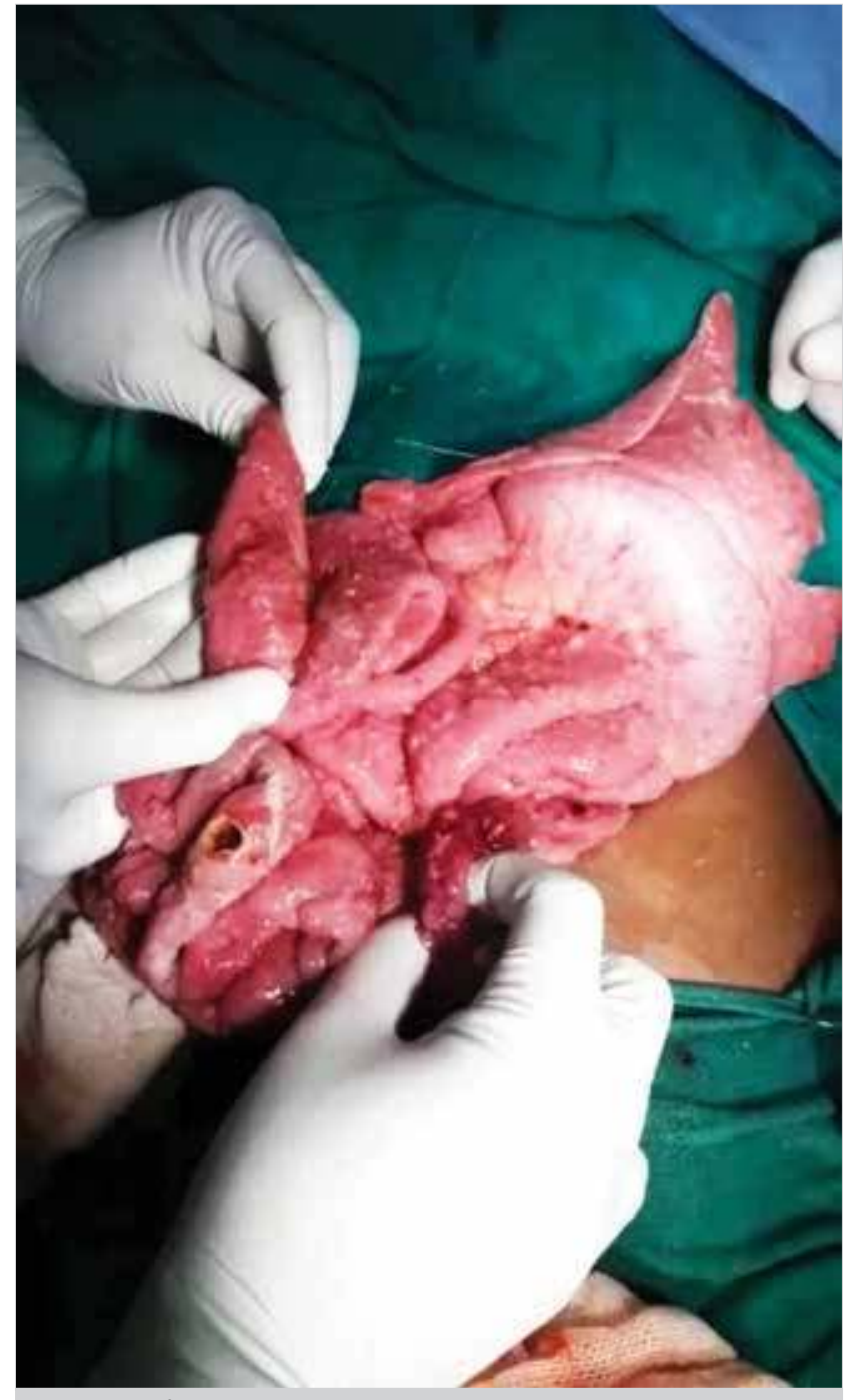

Figure 5. After opening the membrane, underlying bowel shows perforation with studding of bowel by tubercles.

wound care and dressings. In four patients, there was prolonged ileus following surgery and was managed conservatively with nasogastric aspiration and intravenous fluids, which resolved only after 6-8 days after which the patients were gradually started on oral diet.

In the peritonitis group, one patient developed burst abdomen with necrosis of the ileostomy post-operatively. This patient was re-explored on the $7^{\text {th }}$ postoperative day and refashioning of the stoma was done with closure of the abdominal wall with tension sutures. Another patient with PP developed postoperative hypercalcemia (serum calcium $=13 \mathrm{mmol} / \mathrm{L}$ with normal parathormone levels) which was unresponsive to standard treatment. This patient ultimately developed sepsis with multiple organ dysfunction (MODS) and lost on $11^{\text {th }}$ postoperative day (POD), which was the only mortality in our study. Histopathological examination (HPE) of the adhesion band in this 
patient later revealed carcinoma. HPE of all other patients was suggestive of tuberculosis, except in one patient who was already on ATT, it showed only chronic inflammation. All patients documented with tuberculosis were started on ATT.

\section{DISCUSSION}

Abdominal cocoon or sclerosing encapsulating peritonitis is an uncommon condition. Two varieties of this condition have been described: Primary and Secondary. Primary or idiopathic form is most commonly seen in adolescent girls and retrograde menstruation with viral infection has been postulated as a cause although it has not been validated as yet since the condition is also found in men (4).

The secondary form where there is a definite cause has been associated with the use of practolol, abdominal tuberculosis, chronic ambulatory peritoneal dialysis, sarcoidosis, systemic lupus erythematosus, cirrhosis and ventriculoperitoneal and peritoneovenous shunts (5). In our part of the world, tuberculosis is an important cause of the condition. Singh et al. (6) and Wani et al. (7), in their studies, have reported abdominal tuberculosis as causing cocoon abdomen in nine (out of 18) and eleven (out of 11) patients, respectively. In our study, we also found tuberculosis in six of the patients while one patient was already taking ATT for pulmonary tuberculosis.

In our study, one case was diagnosed as adenocarcinoma with IHC suggestive of origin from the gastrointestinal tract or peritoneum. Although rarely reported in the literature, a few studies have described malignancy as a causative factor of SEP. Jimil et al. (8) have described metastatic mucinous adenocarcinoma in their patient causing cocoon carcinomatosa. Katz et al. (9), in their patient, have indicated moderately differentiated adenocarcinoma as the cause of SEP with immunohistochemistry suggestive of origin from peritoneum or ovary. Similarly, Wang et al. (10) have described cocoon-like formations in patients with stage IV gastroentero-pancreatic NETs and postulated that SEP may be a terminal culmination point in the disease progression of this condition.

The clinical presentation of SEP is usually non-specific and includes colicky abdominal pain, vomiting, nausea, or constipation. Rarely, SEP may present with perforation peritonitis. Patients usually report to the emergency departments with signs and symptoms of intestinal obstruction or perforation and usually undergo operations on an urgent basis (11).

Conventional radiographs may show air fluid levels in patients who present with intestinal obstruction or free gas under the diaphragm in patients with peritonitis.

USG findings, though not confirmatory, include dilated bowel segments encased by a dense fibrous membrane or free abdominal fluid and a thickened peritoneal layer (12). However, these findings are non-specific and can be found in many other inflammatory processes of the peritoneum.

Contrast-enhanced computed tomography (CECT) is the most helpful radiological tool for confirming the diagnosis, planning therapy, and avoiding unnecessary resection in patients with SEP (11). Characteristic CT finding helpful in clinching the diagnosis is conglomeration of contrast dense small bowel loops in the centre encased by contrast free capsule in the periphery (3).

Appropriate treatment of this condition is controversial. In patients with mild symptoms, conservative treatment with total parenteral nutrition, nasogastric decompression and peritoneal rest is usually attempted as a first measure as in most cases of intestinal obstruction. In this subset of patients, various drugs have been found to be helpful in ameliorating the fibrotic process include colchicine, steroids, and immunosuppressive agents like azathioprine and mycophenolate mofetil (13).

Surgery, however, remains the mainstay of treatment in most cases. The basis of any surgery is the removal of the membrane and division of any adhesions. Various procedures described in the literature include resection of the peritoneum and fibrous tissue and separation of adhesions to release the bowel, partial membrane excision with adhesiolysis, resection and anastomosis, resection and anastomosis with protective stoma, depending on patient-related factors $(3,14)$. However, Wang et al. (10) have found surgery not very helpful in patients with cocoon secondary to carcinoma in their study.

Meticulous surgical technique is essential to prevent iatrogenic bowel injuries. In our experience at two points of time, extreme care is to be exercised during surgery. First is while opening the peritoneum, which is quite thickened in these patients and densely adherent to the cocoon membrane. While opening the peritoneum, there is a danger of inadvertent entry into the bowel. Second is to find an adequate spot for entry into the cocoon. In our experience, it is easier to open the membrane near the apex of the cocoon as the bowel is not much adherent at this site. Rest of the dissection is usually straightforward as a well-defined plane is usually present between the membrane and bowel. Another thing of note is that in patients with peritonitis complicating the cocoon, the bowel and membrane form one thick adherent plastered layer in which dissection is virtually impossible. The wise thing to do in this group of patients is to perform an ileostomy and not to attempt complete removal of the membrane.

Postoperative period is usually prolonged and rough in these patients. The most common postoperative complications are early postoperative small bowel obstruction, intra-abdominal infection, entero-cutaneous fistula, short bowel syndrome, and bowel perforation (11). In our study, we observed prolonged ileus and delayed return of bowel movements in many patients 
probably due to extensive dissection, which, however, resolved with conservative approach in all the patients.

\section{CONCLUSION}

In conclusion, cocoon abdomen or SEP is a rare condition. Most cases are detected at laparotomy. Surgical technique should be meticulous and consist of dissection and excision of the membrane. Tuberculosis should always be considered as a possible etiology in endemic areas. In cases of carcinoma, it usually represents a final result of the disease pathway and surgery is seldom of any benefit.

Ethics Committee Approval: Ethics committee approval was not needed as all patients presented with acute abdomen and needed surgical intervention.

Informed Consent: Informed consent was taken from all the patients before surgery.

Peer-review: Externally peer-reviewed.

Author Contributions: Consept - M.B.; Design - M.B.; Supervision - S.R.; Resource - M.B.; Materials - S.R.; Data Collection and/or Processing - M.B.; Analysis and Interpretation - M.B.; Literature Search - S.R.;Writing Manuscript - M.B., S.R.; Critical Reviews - M.B., S.R.

Conflict of Interest: The authors have no conflicts of interest to declare.

Financial Disclosure: The authors declared that this study has received no financial support.

\section{REFERENCES}

1. Foo KT, Ng KC, RauffA, Foong WC, Sinniah R. Unusual small intestinal obstruction in girls: the abdominal cocoon. Br J Surg 1978; 65: 427-30. [CrossRef]

2. Da Luz MM, Barral SM, Barral CM, Bechara C de S, Lacerda-Filho A. Idiopathic encapsulating peritonitis: report of two cases. Surg Today 2011;41:1644-8. [CrossRef]
3. Allam T, Al Yahri H, Mathew S, Darweesh A, Suliman AN, Abdelaziem $S$, et al. The enigma of primary and secondary encapsulating peritoneal sclerosis. BMC Surgery 2016; 16: 81. [CrossRef]

4. Li N, Zhu W, Li Y, Gong J, Gu L, Li M, et al. Surgical treatment and perioperative management of idiopathic abdominal cocoon: singlecenter review of 65 cases. World J Surg 2014; 38: 1860-7. [CrossRef]

5. Ranganathan S, Abdullah BJJ, Sivanesaratnam V. Abdominal cocoon syndrome. Hong Kong J Radiol 2003; 6: 201-3.

6. Singh B, Gupta S. Abdominal cocoon: a case series. Int I Surg 2013; 11:325-8. [CrossRef]

7. Imtiaz W, Mohamad O, Arfat W, Mehraj A. Tuberculous abdominal cocoon: original article. Ulus Travma Acil Cerrahi Derg 2010; 16: 508-10.

8. Shah J, Kumar A, Singh H, Agarwala R, Sharma V, Rana SS. Cocoon carcinomatosa: An unusual cause of intestinal obstruction. Drug Discoveries \& Therapeutics 2017; 11:51-3. [CrossRef]

9. Katz CBS, Diggory RT, Samee A. Abdominal cocoon. BMJ Case Rep 2014. [CrossRef]

10. Wang YZ, King H, Diebold A. Cocoon formation in patients with midgut neuroendocrine tumors: A rare and unrecognized final pathway. Pancreas 2013:42: 944-8. [CrossRef]

11. Sami A. Accurate definition and management of idiopathic sclerosing encapsulating peritonitis. World J Gastroenterol 2015; 21:675-87. [CrossRef]

12. Gurleyik G, Emir S, Saglam A. The abdominal cocoon: a rare cause of intestinal obstruction. Acta Chir Belg 2010; 110:396-8. [CrossRef]

13. Solak A, Solak I. Abdominal cocoon syndrome: Preoperative diagnostic criteria, good clinical outcome with medical treatment and review of the literature. Turk J Gastroenterol 2012; 23: 776-9. [CrossRef]

14. Akbulut S, Yagmur Y, Babur M. Coexistence of abdominal cocoon, intestinal perforation and incarcerated Meckel's diverticulum in an inguinal hernia: A troublesome condition. World J Gastrointest Surg 2014; 6:51-4. [CrossRef] 


\title{
ORIJINAL ÇALIŞMA-ÖZET
}

Turk J Surg 2019; 35 (3): 171-177

\section{İkincil enkapsüle peritonit: beş yıllık hasta serisi}

\author{
Mansoor Banday ${ }^{1}$, Sehrish Rauof ${ }^{2}$ \\ 1 Esi Lisansüstü Tıp Bilimleri ve Araştırma Enstitüsü ve Hastanesi, Genel Cerrahi Bölümü, Yeni Delhi, Hindistan \\ ${ }^{2}$ Devlet Tıp Fakültesi, Nefroloji Bölümü, Srinagar, Hindistan
}

\section{ÖZET}

Giriş ve Amaç: Abdominal koza veya sklerozan enkapsüle peritonit, koza benzeri bir membran içerisinde bağırsak sıkışması ile karakterize nadir bir durumdur. Birincil ve ikincil türleri tanımlanmıştır. Çoğu hasta bağırsak tıkanıklığı veya peritonit ile akut olarak başvurmakta ama uzun süredir varolan kronik belirti öyküsü de bulunabilmektedir. Görüntüleme yöntemlerinde bu durum tespit edilemeyebilir ve tanı genellikle laparotomi sırasında konulur. Cerrahi tedavi, adezyolizis olan membranın eksizyonudur.

Gereç ve Yöntem: Hastanemizde, beş yıllık süreçte abdominal koza sebebiyle opere edilen hastaların analizi yapıldı. Analiz, hasta belirtileri, görüntüleme bulguları, intraoperatif bulgular ve histopatolojiyi içerdi.

Bulgular: Çalışmaya beş erkek, üç kadın hasta dahil edildi. Ortalama yaş 29.6 idi. Beş hasta akut bağırsak tıkanıklığı üç hasta da perfore peritonit ile başvurdu. Tüm olgulara laparotomi uygulandı. Tıkanıklığı olan tüm hastalarda başarılı bir membran eksizyonu gerçekleştirilirken, perfore peritonit olan hastaların sadece birinde yapılabildi. Histopatolojik inceleme altı hastada tüberküloz tanısı koydu. Bir hasta zaten antitüberküloz tedavisi almaktaydı ve bir hastada karsinom saptandı. Bir hastamızda mortalite görüldü.

Sonuç: Abdominal koza nadir bir durumdur. Endemik bölgelerde tüberküloz her zaman göz önünde tutulmalıdır. Cerrahi, tercih edilen tedavi yöntemi olup membranın eksizyonunu içermektedir fakat peritonit veya maligniteli hastalarda zor olabilir.

Anahtar Kelimeler: Koza karnı, perforasyon peritonit, sklerozan enkapsüle peritonit, tüberküloz, koza karsinomu

DOi: $10.5578 /$ turkjsurg.4143 